\title{
Haplotype associations of three DNA polymorphisms at the human low density lipoprotein receptor gene- locus in familial hypercholesterolaemia
}

\author{
M J KOTZE*, E LANGENHOVEN*, A E RETIEF*, K STEYN†, \\ M P MARAIS $\dagger$, J J GROBBELAAR*, C J J OOSTHUIZEN*, \\ $\mathrm{H}$ F H WEICH $\ddagger$, AND A J S BENADÉ
}

From *the Research Unit for Cytogenetics, Department of Human Genetics, University of Stellenbosc居 Medical School, Tygerberg; the National Research Institute for Nutritional Diseases of the South Africain Medical Research Council, Tygerberg; and $\ddagger$ the Department of Internal Medicine and Bayer Cardiovasculatr Clinical Research Unit, Tygerberg Hospital, Tygerberg 7505, South Africa.

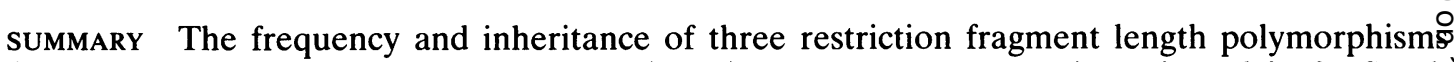
(RFLPs) of the low density lipoprotein (LDL) receptor gene were investigated in 27 Soutb African families with familial hypercholesterolaemia. Four haplotypes, defined by the enzyme $\$$ PvuII, StuI, and NcoI, were found to segregate in this population. The frequency of the rare allele detected by $\mathrm{NcoI}$ was found to be 0.53 in 45 unrelated familial hypercholesterolaemic (FH patients compared to 0.33 in 60 normal controls $(\mathrm{p}<0.005)$. In $71 \%$ of the families studied, a hap $=$ lotype with common alleles for PvuII and StuI and the rare allele for NcoI cosegregated with gh $\xi_{0}^{\circ}$ defective gene. In $20 \%$ of the families, a second haplotype with rare alleles for PvuII and $S \mathrm{~m} u \mathrm{~N}$ and common allele for $\mathrm{NcoI}$ segregated with $\mathrm{FH}$. In these families the haplotypes unambiguous cosegregate with the disease and can therefore be used for early diagnosis of $\mathrm{FH}$.

Mutations in the human gene for the low density lipoprotein (LDL) receptors produce the clinical syndrome of familial hypercholesterolaemia $(\mathrm{FH}){ }^{1}$ These receptors are located in coated pits on the cell surface, bind plasma LDL, and carry it into cells by receptor mediated endocytosis. In patients with $\mathrm{FH}$, the genetically defective receptors cause LDL to accumulate to high levels in plasma, which eventually leads to atherosclerosis.

At least 10 different mutant alleles at the LDL receptor locus can be distinguished through biochemical studies of cultured fibroblasts from $\mathrm{FH}$ patients. ${ }^{2}$ A cDNA clone for the human LDL receptor gene has recently been isolated, ${ }^{3}$ which enables one to study these receptor defects at DNA level. DNA restriction site polymorphisms (RFLPs) around or within structural genes allow identification of alleles, which can be used to study the association with a disease within a population, or segregation of marker alleles and disease within a family.

Received for publication 6 February 1987. Accepted for publication 16 March 1987.
Previous studies have shown that a $P v u$ II restrictio enzyme polymorphism of the LDL receptor gene can be used to show that alleles of this genetio marker coinherit with familial hypercholesterokaemia. ${ }^{4}$

We have previously reported two new RFLPs भI the LDL receptor gene locus. ${ }^{56}$ Both the restrictio $\$$ enzymes StuI and NcoI identify two allele polyo morphisms which are informative for family studies and early diagnosis of $\mathrm{FH}$. In this study we report the frequency of the three LDL receptor gene restriction site polymorphisms in the normocholes terolaemic and $\mathrm{FH}$ populations. A study of haplo type associations with $\mathrm{FH}$ in 27 informative familie今 show a predominant association of two haplotypes with the disease.

Subjects and methods

Blood samples were collected from 45 selected FF patients attending the lipid clinic at Tygerberg Hospital, Tygerberg, South Africa. Pedigree analy ses were performed on 27 of these patients an\& 
blood samples were collected from 292 of the family members. The patients were selected as having FH when the following criteria were fulfilled. Total serum cholesterol levels of all patients had to be at least equal to the 90th centile for their age and sex categories of a typical South African white population. ${ }^{7}$ If patients received cholesterol lowering drugs (cholestyramine, probucol, bezafibrate, or nicotinic acid) in full dose, singly or in combination, they were included in the FH study group only if their total cholesterol level was at least equal to the 70th centile for the age and sex group. All FH study participants had normal serum triglyceride levels equal to or lower than $2.0 \mathrm{mmol} / \mathrm{l}$. In addition, a FH study participant had to have either clinical features of FH (tendon xanthoma of the Achilles tendon or tendons on the dorsum of the hand with or without xanthelasma) or a family history of early coronary heart disease (CHD). An early CHD family history was defined as being present when the FH participant reported that at least two first or second degree relatives suffered CHD before the age of 50 years.

Blood samples from 60 normocholesterolaemic, Afrikaans speaking, white subjects were obtained from the laboratory population and from unaffected spouses of subjects with FH. Total serum cholesterol levels of the normocholesterolaemic study group were not higher than the 50th centile for their age and sex categories of a typical white South African population. ${ }^{7}$ Their serum triglyceride levels were also normal $(\leqslant 2 \mathrm{mmol} / \mathrm{l})$. All the other criteria for $\mathrm{FH}$ were absent in this study group.

\section{LIPID DETERMINATION}

The total cholesterol and high density lipoprotein (HDL) cholesterol levels were measured on a Gilford auto-analyser using the Boehringer CHODPAP enzymatic method. HDL cholesterol was measured after precipitation of the apoprotein B containing lipoproteins with dextran sulphatemagnesium chloride. The triglyceride levels were determined by the Boehringer enzymatic Peridochrom method. In each case the Gilford autoanalyser was calibrated against Precilip or Precilip EL control sera, which were corrected by Boehringer Mannheim for the specific test kit in question. Two control samples were included in each batch analysed.

DNA PREPARATION AND RFLP ANALYSIS DNA was prepared from the blood samples by a Triton-X100 lysis method. ${ }^{8}$ Aliquots of the DNA (5 $\mu \mathrm{g})$ were digested with the restriction enzymes $P v u \mathrm{II}$, StuI, and NcoI, using conditions recommended by the suppliers (Boehringer Mannheim). DNA fragments were separated by size on a $0 \cdot 6 \%$ agarose gel and transferred to nitrocellulose filters (Schleicher and Schnell, BA85, $0.45 \mathrm{~nm}$ ) by the Southern blotting technique. ${ }^{9}$

The human DNA probe for the $\mathrm{LDL}$ receptor gene, pLDLR-2HH1, was obtained from Dr D W Russell of Dallas. It consists of a $1.9 \mathrm{~kb}$ fragment of the $3^{\prime}$ end of the LDL receptor cDNA clone and subcloned into a BamHI site of the vector pSP64. ${ }^{3}$ The insert was excised with $\mathrm{BamHI}$, separated from the vector on a $1 \%$ agarose gel, and recovered. The probe DNA was labelled in vitro by nick translation to a specific activity of $10^{8} \mathrm{cpm} / \mu \mathrm{g}$ (BRL Kit, Amersham International).

Filters were prehybridised for three hours at $65^{\circ} \mathrm{C}$ in $3 \times \mathrm{SSC}(1 \times \mathrm{SSC}: 0 \cdot 15 \mathrm{~mol} / \mathrm{l} \mathrm{NaC} 1,0.015 \mathrm{~mol} / \mathrm{l}$ sodium citrate), $0 \cdot 1 \%$ sodium dodecyl sulphate (SDS), $10 \times$ Denhardt's solution, $50 \mu \mathrm{g} / \mathrm{ml}$ denatured salmon sperm DNA (Sigma), and $10 \mu \mathrm{g} / \mathrm{ml}$ poly A (Sigma). The probe was then added at a concentration of $50 \mathrm{ng} / \mathrm{ml}$ and hybridisations were carried out for 22 hours at $65^{\circ} \mathrm{C}$. Filters were finally washed in $1 \times \mathrm{SSC}, 0 \cdot 1 \%$ SDS and exposed to Kodak XAR film for one to three days.

STATISTICAL ANALYSIS

$\chi^{2}$ tests were performed to document that the populations investigated were or were not in HardyWeinberg equilibrium and to compare the chromosomal frequencies.

\section{Results}

Table 1 shows the results of lipid analysis, the family history of early CHD, and presence of tendon xanthomas in 45 FH patients and 60 controls. Family history denotes the presence of a myocardial infarct or sudden death before the age of 50 years in first or second degree relatives.

Fig 1 shows representative autoradiographs of Southern blots of genomic DNA digested with $P v u I I, S t u I$, and NcoI, hybridised to the radiolabelled LDL receptor gene probe. HindIII digested

TABLE 1 Clinical data of unrelated normocholesterolaemic and $\mathrm{FH}$ subjects.

\begin{tabular}{lcc}
\hline & $F H$ & Normal \\
\hline Number of subjects & 45 & 60 \\
Mean age (y) & $44 \pm 12 \cdot 9$ & $45 \pm 12 \cdot 5$ \\
Mean serum cholesterol (mmol/1) & $9 \cdot 2 \pm 1 \cdot 57$ & $5 \cdot 2 \pm 0 \cdot 68$ \\
Mean plasma HDL (mmol/1) & $1 \cdot 2 \pm 0 \cdot 31$ & $1 \cdot 4 \pm 0 \cdot 58$ \\
Mean serum triglyceride (mmol/1) & $1 \cdot 3 \pm 0 \cdot 36$ & $1 \cdot 2 \pm 0 \cdot 42$ \\
Male/female ratio & $22: 23$ & $20: 40$ \\
$\%$ with tendon xanthomas & 62 & 0 \\
$\%$ with family history of CHD & & 0 \\
$\leqslant 50$ years & 78 & 0 \\
\hline
\end{tabular}




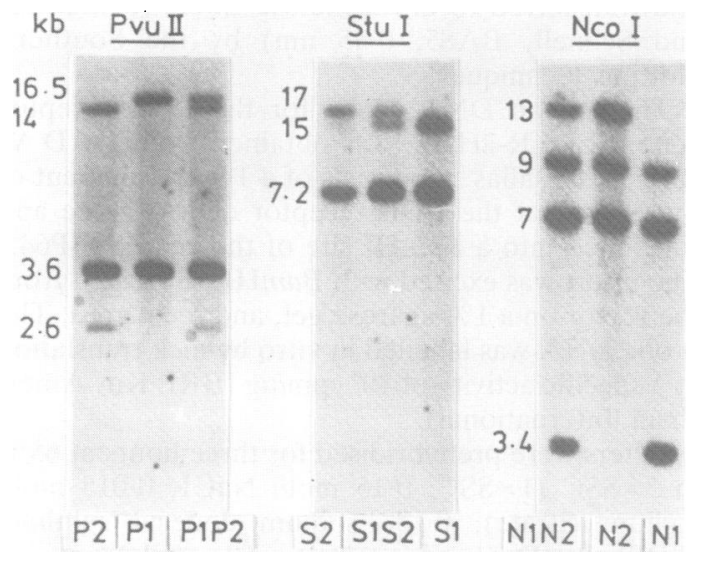

lambda phage fragments were used as DNA size markers with each batch of digests. The genomic DNA of heterozygotes showing recognition sites of $P v u I I, S t u I$, and $N c o I$ are illustrated diagrammatically in fig $2 \mathrm{a}, \mathrm{b}$, and $\mathrm{c}$ respectively. The alleles defined using the restriction enzyme $P v u I I$ are characterised by DNA fragments of 16.5 and $3.6 \mathrm{kbp}$ (P1), and $14,3.6$, and $2.6 \mathrm{kbp}$ (P2). ${ }^{4}$ The alleles defined by $S t u$ I are characterised by two fragments of 15 and $7.2 \mathrm{kbp}(\mathrm{S} 1)$, and 17 and $7.2 \mathrm{kbp}(\mathrm{S} 2),{ }^{5}$ and the alleles defined by $\mathrm{NcoI}$ by fragments of 9,7 , and $3.4 \mathrm{kbp}$ (N1), and 9, 7, and $13 \mathrm{kbp}(\mathrm{N} 2)$ respectively. ${ }^{6}$ The approximate map of fragment sizes in fig 2 is derived from Südhof $e a^{a l^{10}}$ and from DNA double digests using sets of different restriction enzymes. The variable StuI and NcoI sites are respectively located in exons 8 and 18 of the LDL receptor gene.
FIG 1 Southern blot analysis of the LDL receptor gene DNA polymorphisms. The hybridisation pattern obtained from digests of $5 \mu \mathrm{g}$ DNA with PvuII, StuI, and Ncol from three normal subjects are shown. Fragment sizes are indicated in $k b$. The common alleles are designated $P 1, S 1$, and N1 and the rare alleles designated P2, S2, anc $N 2$, respectively.

RFLP GENOTYPES AND ALLELE FREQUENCIES IN FH AND NORMOCHOLESTEROLAEMIC POPULATIONS

The distribution of genotypes and frequencies of the 3 three RFLP alleles were determined in 60 normo-믐 cholesterolaemic and 45 unrelated $\mathrm{FH}$ subjects (table 2). The distribution of genotypes is close $\$ 0 \infty$ the expected value if the population is in Hard Weinburg equilibrium, but a statistically significañit increase in the rare allele of the $\mathrm{Ncol}$ polymorphism above the values in the normocholesterolaemic $\bar{\partial}$ group was found in the $\mathrm{FH}$ population $\left(\chi^{2}=17 \cdot 2\right.$, ्ֶ? $\mathrm{p}<0.005)$. This indicates population association of $\stackrel{\mathbb{Q}}{\Omega}$ this allele with a gene predisposing to hyper- $\overrightarrow{\overrightarrow{0}}$ cholesterolaemia. For the StuI and PvuII RFLPs there is no statistically significant difference in allele frequency between the normocholesterolaemic ando $\mathrm{FH}$ populations.

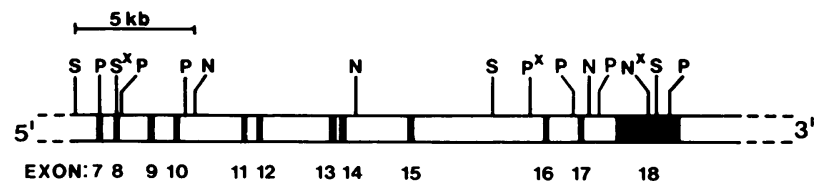

(a)

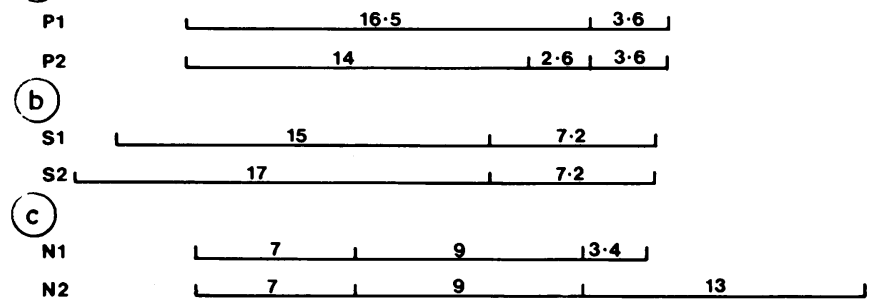

FIG 2 Diagrammatic representation of sites and approximate fragment sizes of the human $L D L$ receptor gene RFLPs. $P^{x}, S^{x}$, and $N^{x}$ represent the polymorphic sites for the enzymes PvuII, StuI, and NcoI respectively. The diagrams show genomic $D N A$ fragments detected with the $L D L$ receptor probe pLDLR-2HHI in P1P2 (a), S1S2 (b), and N1N2 (c) heterozygotes. 
A study of the genotype combinations of the three RFLPs show that only 10 of the possible 27 genotype combinations occur in both populations (table 3 ), with four of the possible eight haplotypes (table 4). Genotype combinations were obtained directly from Southern blot analysis, while haplotypes were deduced if the subjects were homozygous for at least two of the polymorphisms. Where possible, the hap-

TABLE 2 Comparison of genotype distribution and allele frequencies of the PvuII, StuI, and Ncol RFLPs in the normocholesterolaemic and FH populations.

\begin{tabular}{llllll}
\hline Enzyme & \multicolumn{2}{l}{ No of subjects } & & \multicolumn{2}{l}{ Allele frequency } \\
\hline PvuII & $\mathrm{P} 1-1$ & $\mathrm{P} 1-2$ & $\mathrm{P} 2-2$ & $\mathrm{P} 1$ & $\mathrm{P} 2$ \\
Normal $\mathrm{n}=60$ & 28 & 26 & 6 & 0.68 & 0.32 \\
FH $\mathrm{n}=45$ & 27 & 14 & 4 & 0.76 & 0.24 \\
& & & & & \\
StuI & $\mathrm{S} 1-1$ & $\mathrm{~S} 1-2$ & $\mathrm{~S} 2-2$ & $\mathrm{~S} 1$ & $\mathrm{~S} 2$ \\
Normal $\mathrm{n}=60$ & 51 & 9 & 0 & 0.93 & $(0.07$ \\
FH $\mathrm{n}=45$ & 37 & 7 & 1 & 0.90 & 0.10 \\
& & & & & \\
NcoI & $\mathrm{N} 1-1$ & $\mathrm{~N} 1-2$ & $\mathrm{~N} 2-2$ & $\mathrm{~N} 1$ & $\mathrm{~N} 2$ \\
Normal $\mathrm{n}=60$ & 26 & 28 & 6 & 0.67 & 0.33 \\
FH $\mathrm{n}=45$ & 7 & 28 & 10 & 0.47 & 0.53 \\
\hline
\end{tabular}

Normal vs FH frequency $\chi^{2}=17 \cdot 2(1 \mathrm{df}), \mathrm{p}<0 .(0) 5$.

TABLE 3 Genotype frequencies of the three polymorphisms of the $L D L$ receptor gene in the normal and $\mathrm{FH}$ populations.

\begin{tabular}{lccccc}
\hline Genotype & \multicolumn{2}{c}{$F$ subjects } & $(n=45)$ & & \multicolumn{2}{c}{ Normal subjects $(n=60)$} \\
\cline { 2 - 3 } & $N o$ & $\%$ & & No & $\%$ \\
\hline P1P1S1S1N1N1 & 0 & 0 & 9 & 15 \\
P1P1S1S1N1N2 & 17 & $38^{*}$ & 14 & $23^{*}$ \\
P1P1S1S1N2N2 & 10 & $22^{*}$ & 5 & $8^{*}$ \\
P1P2S1S1N1N1 & 1 & 2 & 8 & 13 \\
P1P2S1S1N1N2 & 8 & 18 & 11 & 18 \\
P1P2S1S2N1N1 & 2 & 4 & & 5 \\
P1P2S1S2N1N2 & 3 & 7 & 4 & 7 \\
P2P2S1S1N1N1 & 1 & 2 & & 4 & 7 \\
P2P2S1S2N1N1 & 2 & 4 & & 3 \\
P2P2S2S2N1N1 & 1 & 2 & & 0 \\
\hline
\end{tabular}

${ }^{*}$ See text.

TABLE 4 Haplotype frequencies of the three polymorphisms of the $L D L$ receptor gene in the normal and $F H$ populations.

\begin{tabular}{|c|c|c|c|c|}
\hline \multirow[t]{2}{*}{ Haplotype } & \multicolumn{2}{|c|}{ FH population $(n=86)$} & \multicolumn{2}{|c|}{ Normal population $(n=92)$} \\
\hline & $\begin{array}{l}\text { No of } \\
\text { chromosomes }\end{array}$ & $\%$ & $\begin{array}{l}\text { No of } \\
\text { chromosomes }\end{array}$ & $\%$ \\
\hline P1SIN1 & 20 & 23 & 39 & 42 \\
\hline P1SIN2 & 46 & $54^{*}$ & 29 & $32^{*}$ \\
\hline P1S2N1 & 0 & 0 & 0 & 0 \\
\hline P1S2N2 & 0 & 0 & 0 & 0 \\
\hline P2S1N1 & 11 & 13 & 21 & 23 \\
\hline $\mathrm{P} 2 \mathrm{~S} 1 \mathrm{~N} 2$ & 0 & 0 & 0 & 0 \\
\hline $\mathrm{P} 2 \mathrm{~S} 2 \mathrm{~N} 1$ & 9 & 10) & 3 & 3 \\
\hline $\mathrm{P} 2 \mathrm{~S} 2 \mathrm{~N} 2$ & 0 & 0 & 0 & 0 \\
\hline
\end{tabular}

${ }^{*}$ See text. lotypes of double heterozygotes were inferred from the pedigree. (There were 14 double heterozygotes in the normal population and two in the $\mathrm{FH}$ population for whom pedigree information was unavailable, so they are therefore not included.) Haplotypes for 43 unrelated FH ( 86 haplotypes) and 46 normocholesterolaemic subjects (92 haplotypes) are shown in table 4.

The demonstration of only a few genotype and haplotype combinations in the populations can be interpreted as non-random association of the three DNA markers of the LDL receptor gene. One of the haplotypes, P1S1N2, shows a significantly higher incidence in the $\mathrm{FH}$ group $(32 \%$ in normocholesterolaemics compared with $54 \%$ in hypercholesterolaemics). The predominance of the $\mathrm{N} 2$ allele of the NcoI polymorphism in FH subjects is clear in tables 2 and 3.

\section{SEGREGATION OF THE RFLP HAPLOTYPES IN} FH FAMILIES

We have used the PvuII, StuI, and NcoI polymorphisms to follow the inheritance of the LDL receptor gene in 27 informative families in which $\mathrm{FH}$ occurs. In 17 families (46 normal and 75 affected offspring) the P1S1N2 haplotype and the FH phenotype cosegregated. An example of one extended family is shown in fig $3 \mathrm{a}$. The $\mathrm{FH}$ phenotype was associated with the P2S2N1 haplotype in seven informative families, where 38 normal and 46 affected offspring were analysed (example of one family in fig 3b). The P1S1N1 haplotype has shown association with the $\mathrm{FH}$ phenotype in two families (four normal and eight affected offspring) and the P2S1N1 haplotype in only one family (seven normal and eight affected offspring).

Table 5 shows the frequencies of the different haplotypes associated with $\mathrm{FH}$ in 34 unrelated $\mathrm{FH}$ heterozygotes. The $\mathrm{FH}$ haplotypes were deduced from the pedigree analyses in the 27 families and from seven patients homozygous for all three RFLPs. In $71 \%$ of the FH families studied, the P1S1N2 haplotype cosegregates with the defective gene, while the P2S2N1 haplotype segregates in $20 \%$ of families. The P1S1N1 and P2S1N1 haplotypes are associated with the $\mathrm{FH}$ phenotype in only $6 \%$ and $3 \%$ of families studied, respectively.

TABLE 5 Frequencies of haplotypes associated with the FH phenotype.

\begin{tabular}{lcr}
\hline Haplotype & No of subjects $(n=34)$ & $\%$ \\
\hline P1S1N1 & 2 & 6 \\
P1S1N2 & 24 & 71 \\
P2S1N1 & 1 & 3 \\
P2S2N1 & 7 & 20 \\
\hline
\end{tabular}




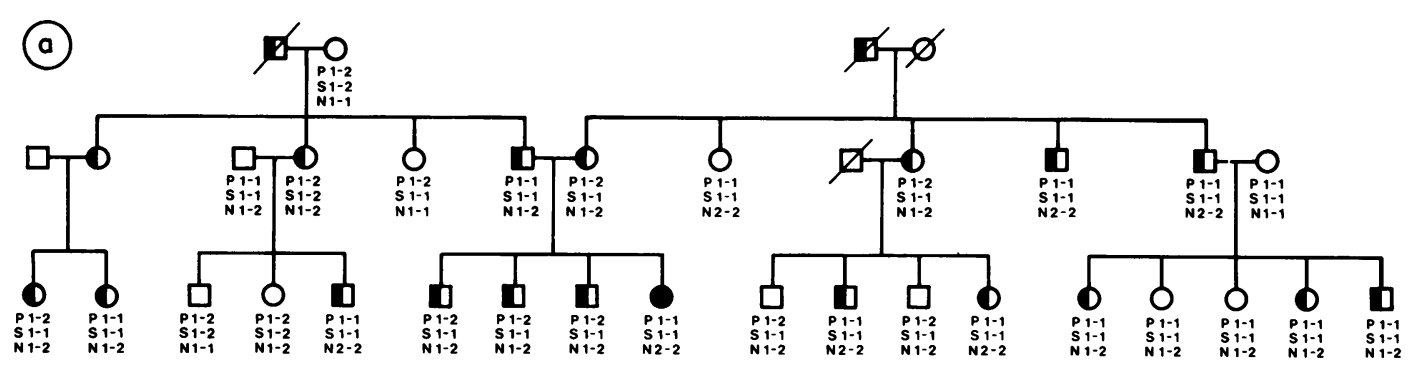

(b)

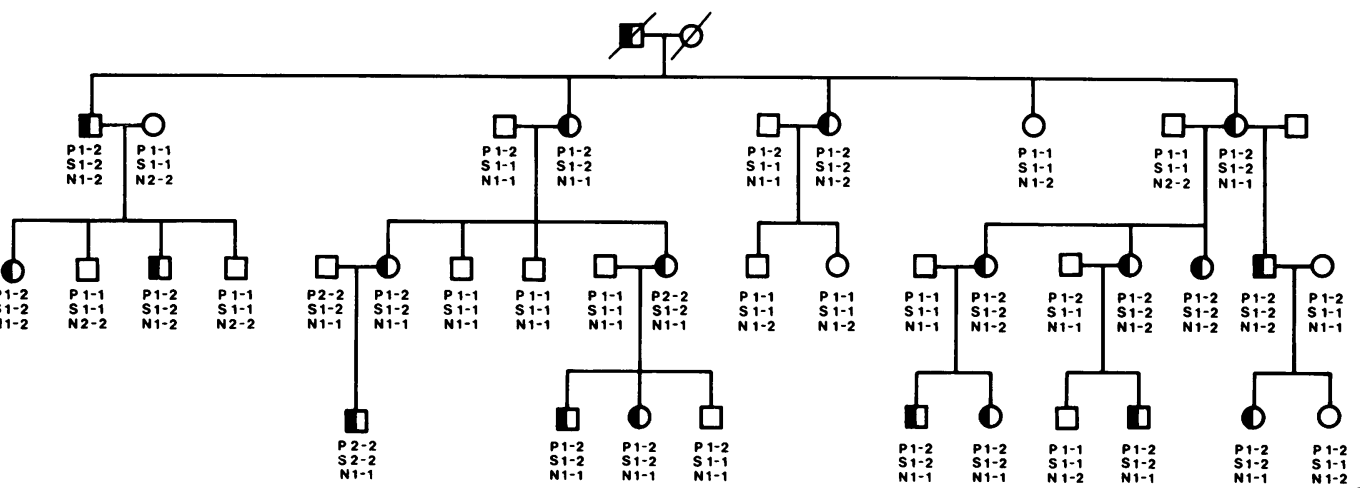

\section{$\square \bigcirc$ Normal male and female \\ DD FH male and female (heterozygous) \\ D. FH male and female (homozygous)}

FIG 3 Segregation of FH and the LDL receptor gene RFLPs in two families. (a) FH phenotype associated with the PISIN2 haplotype. (b) FH phenotype associated with the P2S2N1 haplotype.

The association of the P1S1N2 and P2S2N1 haplotypes with $\mathrm{FH}$ in the white South African population were further confirmed in five clinical FH homozygotes. Four have shown P1P1S1S1N2N2 genotypes, while one is a heteroallelic genetic compound with a P1P2S1S2N1N2 genotype, containing both the P1S1N2 and P2P2N1 haplotypes. The haplotypes were deduced from family studies. The haplotypes and lipid results of five FH homozygotes are shown in table 6 .

\section{Discussion}

The prevalence of $\mathrm{FH}$ in South Africa is unusually high and a 'founder gene' effect in the Afrikaner population has been proposed. ${ }^{11}$ LDL receptor studies of South African FH homozygotes have shown a predominance of a receptor defective type of abnormality. ${ }^{12}$

In our study using three DNA polymorphisms at the human LDL receptor gene in $45 \mathrm{FH}$ and 60

TABLE 6 Haplotypes and lipid results of five homozygous FH patients.

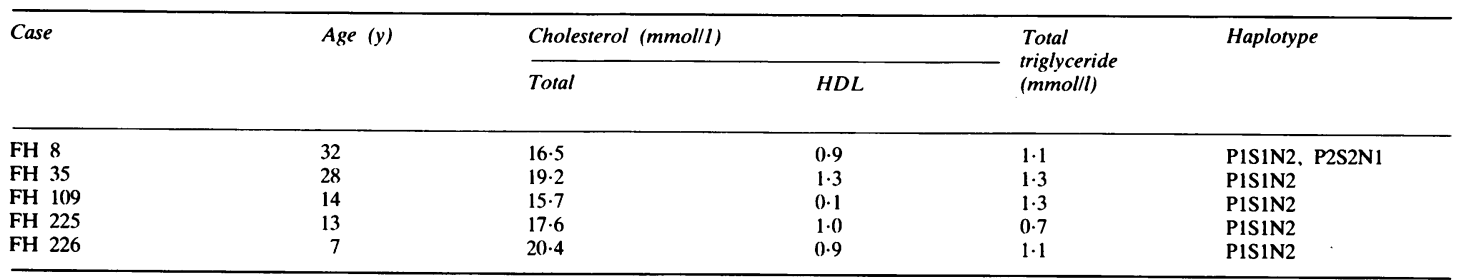


normocholesterolaemic subjects, we have found a statistically significant excess of the rare $\mathrm{N} 2$ allele of the NcoI RFLP in the FH population. The PvuII, StuI, and NcoI RFLPs have been used to follow the inheritance of the LDL receptor gene in 27 informative $\mathrm{FH}$ families. In $71 \%$ of these the P1S1N2 haplotype cosegregated with the defective gene. This association was further confirmed in five $\mathrm{FH}$ homozygotes. Four were homozygous for the P1S1N2 haplotype and one a genetic compound with both the P1S1N2 and P2S2N1 haplotypes; in $20 \%$ of $\mathrm{FH}$ families studied the $\mathrm{FH}$ phenotype cosegregated with the P2S2N1 haplotype. The P1S1N1 and P2S1N1 haplotypes have been associated with the FH phenotype in only $6 \%$ and $3 \%$ of families studied respectively. Studies are under way to confirm these rare FH haplotypes in clinical FH homozygotes.

If, as expected for polymorphisms around a single gene, there is no recombination between the three RFLPs, it will be possible to combine the information on all three RFLPs to form an unequivocal haplotype for any subject. In the 27 families studied so far, we have observed no recombination within the DNA region of the LDL receptor gene covered by the three RFLPs. Analyses of associations of RFLPs have revealed only four of the possible eight haplotypes. This may be an indication that the PvulI, StuI, and NcoI RFLPs are non-randomly associated. Since the S2 allele is found only in association with the P2 allele, whereas the S1 allele is found with both the P1 and P2 allele, it is likely that the PvuII polymorphism evolved before the StuI polymorphism. The base pair changes creating the loss of a StuI site must have arisen on a chromosome 19 with a P2 genotype. Similarly we can postulate that the PvuII polymorphism has arisen in the presence of the $\mathrm{N} 1$ allele, since the $\mathrm{N} 2$ allele is never found in association with $\mathrm{P} 2 \mathrm{~S} 1$ or P2S2 genotypes.

Haplotype analysis alone is not sufficient to distinguish normal from $\mathrm{FH}$ chromosomes, since the same haplotypes were found in both the normal and FH populations. This finding is interpreted as an indication that the LDL receptor gene haplotypes were established at a point in evolution before the mutations causing FH. It further implies that the FH mutations evolved independently from one another, suggesting that a particular mutation is likely to be associated with a specific haplotype. Variations at these three polymorphic sites may serve as valuable genetic markers, for the identification of different
FH mutations, for population studies, and as a basis for prenatal diagnosis of many $\mathrm{FH}$ mutations.

We thank Emmie Bedeker and the nursing staff of Genetic Services, Department of Health and Welfare for collecting the blood samples. This work was supported by the South African Medical Research Council, the University of Stellenbosch, the Cape Provincial Administration, and the Stichting Stellenburg.

\section{References}

1 Goldstein JL, Brown MS. Familial hypercholesterolemia. In: Stanbury JB, Wyngaarden JB, Frederickson DS, Goldstein JL, Brown MS, eds. The metabolic basis of inherited disease. 5th ed. New York: McGraw-Hill, 1983: 672-712.

2 Goldstein JL, Brown MS. Progress in understanding the LDL receptor and HGM-CoA reductase, two membrane proteins that regulate the plasma cholesterol. J Lipid Res 1984:25: $1450-61$.

3 Yamamoto T, Davis CG, Brown MS, et al. The human LDL receptor: a cysteine-rich protein with multiple Alu sequences in its mRNA. Cell 1984;39:27-38.

${ }^{4}$ Humphries SE, Horsthemke B, Seed M, et al. A common DNA polymorphism of the low-density lipoprotein (LDL) receptor gene and its use in diagnosis. Lancet 1985; i:1003-5.

5 Kotze MJ, Retief AE, Brink PA, Weich HFH. A DNA polymorphism in the human low-density lipoprotein receptor gene. $S$ Afr Med J 1986;70:77-9.

${ }^{6}$ Kotze MJ, Langenhoven, E, Dietzsch E, Retief AE. A RFLP associated with the low-density lipoprotein receptor gene. Nucleic Acids Res 1987;15:376.

7 Rossouw JE, Jooste PL, Steyn K, Benadé AJS. Serum total and high-density lipoprotein cholesterol-reference values obtained in the Coronary Risk Factor Study baseline survey. S Afr Med J 1985;67:533-8.

${ }^{8}$ Kunkel LM, Smith KD, Boyer SH, et al. Analysis of human Y-chromosome-specific reiterated DNA in chromosome variants. Proc Natl Acad Sci USA 1977;74:1245-9.

${ }^{9}$ Southern EM. Detection of specific sequences among DNA fragments separated by gel electrophoresis. J Mol Biol 1975;98: 503-17.

10 Südhof TC, Goldstein JL, Brown MS, Russel DW. The LDL receptor gene: a mosaic of exons shared with different proteins. Science 1985;228:815-22.

"Seftel HC, Baker SG, Sandler MP, et al. A host of hypercholesterolemic homozygotes in South Africa. $\mathrm{Br}$ Med J 1980;281:633-6.

12 Coetzee GA, Van der Westhuizen DR. Familial hypercholesterolemia - a receptor defect. S Afr J Cont Med Educ 1984;2: 49-56.

Correspondence and requests for reprints to Professor A E Retief, Department of Human Genetics, University of Stellenbosch, Medical School, PO Box 63, Tygerberg 7505, South Africa. 